\title{
Eğitim Fakültesi Öğrencilerinin Akademik Öz-Yeterlik Durumlarının İncelenmesi
}

\author{
Agâh Tuğrul KORUCU*, Derya ÇINAR**
}

Öz: Öğretmen adaylarının akademik öz-yeterlik durumlarının; akademik yaşantılarında

önemli bir etkiye sahip olduğundan; bu çalışmanın amacı eğitim fakültesi öğrencilerinin akademik öz-yeterlik durumlarının farklı değişkenler açısından belirlenip yorumlanmasıdır.

Araştırmada araştırma yöntemi olarak nicel araştırma benimsenmiş olup, tarama modeli kullanılmıştır. Araştırmanın çalışma grubunu Necmettin Erbakan Üniversitesi Ahmet Keleşoğlu Eğitim Fakültesi’ndeki 18 ayrı bölümde öğrenimine devam eden 913 öğretmen adayı oluşturmaktadır. Veri toplama aracı olarak araştırmacılar tarafından geliştirilen ve çalışma grubu öğrencilerinin demografik verilerinin elde edildiği kişisel bilgi formu, Owen ve Froman (1988) tarafından geliştirilen ve Ekici (2012) tarafından Türkçe'ye uyarlanan “Akademik Öz-Yeterlik Ölçeği” kullanılmıştır. Ölçeğin Türkçeye uyarlanmış hali 33 madde ve 5'li likert tip, 3 alt boyuttan oluşmaktadır. Ölçeğin iç tutarlılık katsayısı Cronbach's alfa değeri .86 bulunmuştur. Verilerin çözümlenmesinde bilgisayar destekli istatistik paket programı olan SPSS kullanılmış; betimsel istatistikler, t-testi, tek yönlü varyans analizi ve basit korelasyon tekniklerinden yararlanılmıştır. Araştırma sonucunda, öğretmen adaylarının; akademik öz-yeterlik durumları öğrenim gördükleri bölümlere göre, öğrenim gördükleri sınıflara göre, mezun oldukları lise türlerine göre değişmektedir. Ayrıca, Öğretmen

* Yrd. Doç. Dr., Necmettin Erbakan Üniversitesi, Ahmet Keleşoğlu Eğitim Fakültesi Bilgisayar ve Öğretim Teknolojileri Eğitimi Bölümü, Konya / TÜRKIYYE, e-posta: akorucu@konya.edu.tr

** Dr., Necmettin Erbakan Üniversitesi, Ahmet Keleşoğlu Eğitim Fakültesi Sınıf Öğretmenliği Bölümü, Konya / TÜRKIYE, e-posta: dcinar@konya.edu.tr 
adaylarının; akademik öz-yeterlik durumları ile yaşları arasında; düşük düzeyde, pozitif yönlü ve anlamlı bir ilişki bulunmuştur.

Anahtar Sözcükler: Akademik Öz-yeterlik, Öz-yeterlik, Öğretmen Adayı, Bireysel Farklılıklar.

\section{The Examination of Faculty of Education Students' Academic Self-Efficacy}

Abstract: Since teacher candidates' academic self-efficacy has a significant impact on their academic life, the purpose of this paper is to determine and interpret academic self-efficacy of faculty of education students in terms of different variables. In this research, the quantitative research method is adopted and survey model is used. Working group includes 913 pre-service teachers from 18 various department of Necmettin Erbakan University Ahmet Keleşoğlu Faculty of Education. As data collection tool, personal information form developed by researchers and used to obtain demographic data of working group students and Academic self-efficacy scale developed by Owen and Froman (1988) and adapted to Turkish by Ekici (2012) are used. Turkish version of the scale consists of 33 items in 5-item likert type and 3 sub-dimensions. The internal consistency coefficient Cronbach'salfa is calculated as .86. In order to analyze data, computer supported statistics package program SPSS is used; descriptive statistics, t-test, One-way analysis of variance and simple correlation techniques are utilized. As a result of the research, Academic self-efficacy status varies according to the 
level of education they graduate according to the classes they graduate from. In addition, Teacher candidates' between academic self-efficacy status and ages; There was a, positive and meaningful and at a lower level relationship.

Key words: Academic Self-efficacy, Self-efficacy, Teacher Candidate, Individual Differences.

\section{Giriş}

Öğretmen adaylarının nitelikli bir şekilde yetişmesinde ve sahip olmaları gereken yeterliklerden birisi öz-yeterliktir. Öz-yeterlik, bireyin bir görevi veya işi başarıyla tamamlamak için bilgilerini, becerilerini organize edebilmesine ve uygulayabilmesine olan güvenidir (Yılmaz, Gürçay ve Ekici, 2007). Bu kavram bireylerin problem çözme becerilerindeki bireysel farklılıkları ifade etmektedir. Bir başka ifadeyle, öz-yeterlik yeteneklere olan inancı ve hedeflere ulaşmak için gerekli bir davranışları ortaya koyabilmektir. (Bandura, 1997). Jerusalem (2002) öz-yeterliği, kişinin yetenekleri konusunda kendisini ikna etmesi olarak tanımlamıştır. Bandura (1995) ise, öz-yeterlik inancını, " bireylerin istenilen performansı sergilemesi için gerekli etkinlikleri düzenleyip başarılı bir biçimde uygulayabilmesi inancı " (s.2) olarak ifade etmiştir. Bu tanıma göre öz-yeterlik inanc1, eğitim uygulamalarında üzerinde durulması gereken önemli kavramlardan biri olarak görülmektedir (Aşkar ve Umay, 2001).

Sosyal öğrenme kuramının savunucusu Bandura'ya $(1995,1977)$ göre bireylerin özyeterlik inancını ortaya koyabilmek için dört bileşen vardır. Bu bileşenler; Bireylerin, 1- 
performans başarıları, 2- deneyimleri, 3- sözel olarak ikna edilmesi ve 4- fiziksel / duygusal durumudur. Bu kaynaklara bağlı ortaya çıkan öz-yeterlik algılarının en önemlilerinden biri akademik öz-yeterliktir. Akademik öz-yeterlikle ilgili farklı tanımlar alan yazında mevcuttur; Zimmerman'a (2000) göre, bireyin bireysel olarak akademik bir işi başarıyla bitirebileceğine yönelik inançtır. Farklı bir tanımda ise, akademik öz-yeterlik, bireylerin hedefledikleri başarılarına ulaşabilmeleri için gerçekleştirmiş oldukları bireysel çabalardır (Bandura, 1997a; Schunk, 1991). Bu durumda, akademik öz-yeterlik düzeyi yüksek bireyler, öğrenme yaşantılarındaki etkinliklerinde daha isteklidirler ve bu etkinlikleri başarıyla tamamlayabilmede daha fazla çaba göstermektedirler. Ayrıca bu bireyler karşılaştıkları güçlükler karşısında daha etkili stratejiler oluşturmaktadırlar. Lent, Brown ve Larkin (1986) araştırmalarında akademik öz-yeterlikleri yüksek bireylerin, akademik başarılarının da yüksek olduğunu ortaya koymuşlardır. Shell, Murphy ve Bruning'nin (1989) araştırmalarında okuma-yazma etkinliklerindeki başarı ile akademik öz-yeterlik arasında yüksek düzeyde bir ilişki olduğunu bulmuşlardır. Durdukoca (2010) yaptığı araştırmada üniversite öğrencilerinin akademik öz-yeterlik inançlarının farklı demografik değişkenlere göre incelemiş ve sonuç olarak; öğrencilerin akademik öz yeterlik inançlarının öğretim türüne göre anlamlı olarak farklılaşmadığı, sınıf düzeyi ve cinsiyetlere göre ise anlamlı bir farklılık gösterdiğini ortaya koymuştur. Matoti (2011) yapmış olduğu araştırmada, üniversite öğrencilerinin akademik özyeterliklerini değerlendirdiği çalışmanın sonucuna göre, öğrencilerin öğrenim gördükleri 
bölümlere göre akademik öz-yeterlik inançları farklılık göstermiştir. Turgut (2013), matematik eğitimi gören lisans öğrencilerinin akademik öz-yeterlik ile cinsiyet, akademik performans ve sınıf düzeyi arasındaki ilişkiyi araştırmış ve çalışma sonunda, öğrencelerin, akademik öz-yeterlik inançlarının orta düzeyde olduğunu ayrıca bu ölçekten aldıkları puanların akademik performans ve sınıf düzeyine anlamlı bir etkisi olduğunu belirlemiştir. Cinsiyet ve akademik performans arasında anlamlı bir ilişkinin olduğunu fakat cinsiyet, akademik performans ve sınıf düzeyi arasında anlamlı bir ilişkinin olmadığını ortaya koymuştur.

Bedel (2015) yapmış olduğu araştırmada, öğretmen adaylarının akademik özyeterliklerini ve akademik motivasyonlarının ilişkisini araştırdığı çalışmanın sonucuna göre, akademik öz-yeterlik ile akademik motivasyon arasında anlamlı bir ilişki bulmuştur.

\section{Araştırmanın önemi}

Alan yazındaki araştırmaların sonuçlarından hareketle, eğitim öğretimin amacına ulaşmasında, öğretmen adaylarının öğrenim gördükleri lisans programında akademik özyeterlik algılarının ortaya çıkarılması ve öğrencilerin akademik öz-yeterlik algı düzeylerinin yükseltilmesi önem arz etmektedir. Eğitim Fakültelerinde lisans öğrenimi gören öğrencilerin akademik öz-yeterlik algılarını belirlemek için yapılan bu çalışma, öğrencilerin sorunlarına, gereksinimlerine ve eksiklerine; k1saca yeterlik ve yetersizliklerine yönelik geri bildirim vermesi açısından önemlidir. 


\section{Araştırmanın amacı}

$\mathrm{Bu}$ çalışmanın amacı eğitim fakültesi öğrencilerinin akademik Öz-Yeterlik durumlarının farklı değişkenler açısından belirlenip yorumlanmasıdır. Bu genel amacı ortaya koymak için cevaplanan araştırma soruları şunlardır;

1. Öğretmen adaylarının akademik öz-yeterlik durumları öğrenim gördükleri bölümlere göre anlamlı bir farklılık göstermekte midir?

2. Öğretmen adaylarının akademik öz-yeterlik durumları sınıfı düzeylerine göre anlamlı bir farklılık göstermekte midir?

3. Öğretmen adaylarının akademik öz-yeterlik durumları internete erişim durumlarına göre anlamlı bir farklılık göstermekte midir?

4. Öğretmen adaylarının akademik öz-yeterlik durumları haftalık internet kullanım sürelerine göre anlamlı bir farklılık göstermekte midir?

5. Öğretmen adaylarının akademik öz-yeterlik durumları mobil cihaz kullanım yeterlilik düzeylerine göre anlamlı bir farklılık göstermekte midir?

6. Öğretmen adaylarının akademik öz-yeterlik durumları mobil teknolojilere sahip oldukları sürelere göre anlamlı bir farklılık göstermekte midir?

7. Öğretmen adaylarının akademik öz-yeterlik durumları öğrenim gördükleri lise türlerine göre anlamlı bir farklılık göstermekte midir? 
8. Öğretmen adaylarının akademik öz-yeterlik durumları ile yaşları arasında anlamlı bir ilişsi var mıdır?

\section{Yöntem}

\section{Araştırmanın Modeli ve Çalışma Grubu}

Araştırmada nicel araştırma yöntemi benimsenmiş olup, tarama modeli kullanılmıştır.

Araştırmanın çalışma grubunu 2015-2016 eğitim-öğretim yılı, bahar döneminde, Necmettin Erbakan Üniversitesi Ahmet Keleşoğlu Eğitim Fakültesi'ndeki 18 ayrı bölümde öğrenimine devam eden 913 öğretmen adayı oluşturmaktadır.

Araştırmada çalışma grubunda yer alan öğrencilerin cinsiyetlerine ait betimsel sonuçlar Tablo 1' de verilmiştir.

Tablo 1. Çalışma Grubunun Cinsiyet Durumları

\begin{tabular}{ccc}
\hline Cinsiyet & $\mathrm{N}$ & $\%$ \\
\hline Erkek & 624 & 68,3 \\
Kadın & 289 & 31,7 \\
\hline Toplam & 913 & 100,0 \\
\hline
\end{tabular}

Tablo 1'de görüldüğü gibi araştırmaya katılan 913 öğretmen adayından 624'ü $(\% 68,3)$ kadın, 289’u erkek $(\% 31,7)$ öğretmen adayıdır.

Araştırmada çalışma grubunda yer alan öğrencilerin öğrenim gördükleri bölümlere göre dağılımlarına ait betimsel sonuçlar Tablo 2' de verilmiştir.

Tablo 2. Çalışma Grubunun Öğrencilerin Öğrenim Gördükleri Bölümlere Göre Dağılımları

\begin{tabular}{l}
$\begin{array}{l}\text { Öğrenim Gördükleri } \\
\text { Bölümlere }\end{array}$ \\
\hline
\end{tabular}


Sosyal Bilgiler

Coğrafya

İngilizce

Okul Öncesi

Özel Eğitim

Türkçe

Din Kültürü

Fen Bilgisi

Sinif

İlk ögrt. matematik

Fizik

Resim

$\mathrm{Pdr}$

Böte

Almanca

Biyoloji

Orta öğretim Matematik

Tarih

Toplam

60

58

60

77

30

60

37

46

70

61

22

63

58

55

29

54

42

31
6,6

6,4

6,6

8,4

3,3

6,6

4,1

5,0

7,7

6,7

2,4

6,9

6,4

6,0

3,2

5,9

4,6

3,4

100,0

Tablo 2'de görüldüğü gibi araştırmaya katılan 913 öğretmen adayından Sosyal Bilgiler

Öğretmenliği $60(\% 6,6)$, Coğrafya Öğretmenliği $58(\% 6,4)$, İngilizce Öğretmenliği 60 (\%6,6), Okul Öncesi Öğretmenliği $77(\% 8,4)$, Özel Eğitim Öğretmenliği $30(\% 3,3)$, Türkçe Öğretmenliği $60(\% 6,6)$, Din Kültürü ve Ahlak Bilgisi Öğretmenliği 37 (\%4,1), Fen Bilgisi Öğretmenliği $46(\% 5,0)$, Sınıf Öğretmenliği $70(\% 7,7)$, İlköğretim Matematik Öğretmenliği $61(\% 6,7)$, Fizik Öğretmenliği $22(\% 2,4)$, Resim-İş Öğretmenliği 63 (\%6,9), Psikolojik, Danışmanlık ve Rehberlik Öğretmenliği $58(\% 6,4)$, Bilgisayar ve Öğretim Teknolojileri Öğretmenliği 55 (\%6), Almanca Öğretmenliği 29 (\%3,2), Biyoloji Öğretmenliği 54 (\%5,9), Ortaöğretim Matematik Öğretmenliği $42(\% 4,6)$ ve Tarih Öğretmenliği $31(\% 3,4)$ bölümlerinde öğrenim görmektedirler.

\section{Veri Toplama Araçları}


Veri toplama aracı olarak araştırmacılar tarafindan geliştirilen ve çalışma grubu öğrencilerinin demografik verilerinin elde edildiği kişisel bilgi formu, Owen ve Froman (1988) tarafından geliştirilen ve Ekici (2012) tarafından Türkçe’ye uyarlanan Akademik $\ddot{O}_{z}$ Yeterlik Ölçeği kullanılmıştır. Ölçeğin Türkçeye uyarlanmış hali 33 madde ve 5'li likert tip (oldukça fazla (5), fazla (4), kısmen fazla (3), az (2), oldukça az (1)), 3 alt boyuttan oluşmaktadır. Alt boyutlar; sosyal statü, bilişsel uygulamalar ve teknik becerilerden oluşmaktadır. Ölçeğin sosyal statü boyutunun iç tutarlılık katsayısı Cronbach’s alfa değeri .82; bilişsel uygulamalar boyutunun; .82 ve teknik beceriler alt boyutunun .90 olarak bulunmuştur. Ölçeğin genelinin iç tutarlılık katsayısı Cronbach's alfa değeri .86 olarak bulunmuştur. Ölçeğin genelinden alınacak puanlar en yüksek 5x33=165 puan, en düşük ise 1x33=33 puandır. Ölçeğin alt boyutlarından alınacak puanlar; Sosyal statü boyutunda; minimum 10 maksimum 50; Bilişsel uygulamalar boyutunda minimum 19 - maksimum 95; teknik beceriler boyutunda minimum 4 - maksimum 20 puan alınabilmektedir. Sosyal statü boyutunda bulunan maddeler; 2, 3, 4, 11, 14, 15, 16, 17, 25, 27 (toplam 10 madde); bilişsel uygulamalar boyutunda bulunan maddeler; $1,5,6,7,8,9,10,12,13,18,19,20,21,22,24$, 30, 31, 32, 33 (toplam 19 madde) ve teknik beceriler boyutunda bulunan maddeler; 23, 26, 28, 29'dur (toplam 4 madde).

\section{Verilerin Çözümlenmesi}

Araştırma kapsamında elde edilen veriler SPSS (The Statistical Package for The 
Social Sciences) paket programı kullanılarak çözümlenmiştir. Araştırma kapsamında elde edilen veriler parametrik test varsayımlarını karşıladığından $(\mathrm{N}=913)$, verilerin çözümlenmesinde parametrik testlerden yararlanılmıştır. Bu bağlamda, her bir alt amaç için kullanılan testler aşağıda açıklanmıştır.

Katılımcılardan toplanan demografik veriler betimsel istatistik yöntemlerinden frekanslar verilerek açıklanmıştır. Katılımcıların internet erişim durumlarına göre anlamlı bir farklılık gösterip göstermediğini test etmek için, ilişkisiz örneklemler için t-testi kullanılmıştır. Katılımcıların ölçekten aldıkları puanların; haftalık internet kullanım sürelerine, sınıf düzeylerine, öğrenim gördükleri bölüme, mobil cihaz kullanım yeterlilik düzeylerine göre, mobil teknolojilere sahip oldukları sürelere göre ve öğrenim gördükleri lise türlerine göre anlamlı bir farklılık gösterip göstermediğini test etmek için ise, ilişkisiz örneklemler için tek faktörlü varyans analizi (one-way anova) kullanılmıştır. Katılımcıların yaşları ile akademik öz-yeterlik durumları arasındaki ilişkinin incelenmesinde basit korelasyon tekniğinden yararlanılmıştır.

\section{Bulgular ve Yorumlar}

Katılımcıların Akademik Öz-Yeterlik Ölçeğinden aldıkları puanların öğrenim gördükleri bölüme göre sonuçları Tablo3'de, değişkenlik gösterip göstermediğine dair bulgular Tablo 4'de verilmiştir.

Tablo 3. Akademik Öz-Yeterlik Ölçeğinden Aldıkları Puanların Öğrenim Gördükleri Bölüme Göre Sonuçları 


\begin{tabular}{llll}
\hline 1. Sosyal Bilgiler & 60 & 128,20 & 30,34 \\
2. Coğrafya & 58 & 132,22 & 23,60 \\
3. İngilizce & 60 & 133,23 & 26,99 \\
4. Okul Öncesi & 77 & 127,68 & 30,52 \\
5. Özel Eğitim & 30 & 139,56 & 10,65 \\
6. Türkçe & 60 & 130,26 & 22,35 \\
7. Din Kültürü & 37 & 107,56 & 39,12 \\
8. Fen Bilgisi & 46 & 115,84 & 31,61 \\
9. Sinıf & 70 & 128,07 & 25,64 \\
10. İlk Öğrt Matematik & 61 & 106,22 & 25,03 \\
11. Fizik & 22 & 132,04 & 24,64 \\
12. Resim & 63 & 119,19 & 22,44 \\
13. Pdr & 58 & 127,89 & 22,72 \\
14. Böte & 55 & 149,32 & 17,17 \\
15. Almanca & 29 & 128,75 & 26,84 \\
16. Biyoloji & 54 & 108,83 & 23,11 \\
17. Ortaöğretim Matematik & 42 & 117,69 & 26,12 \\
18. Tarih & 31 & 115,09 & 29,01 \\
\hline Toplam & 913 & 124,98 & 28,02 \\
\hline
\end{tabular}

Tablo 4. Katılımcıların Akademik Öz-Yeterlik Ölçeği Toplam Puanlarının Öğrenim Görülen Bölüm Değişkenine Göre Farklılığı İçin Tek Yönlü Varyans Analizi (ANOVA) Sonuçları

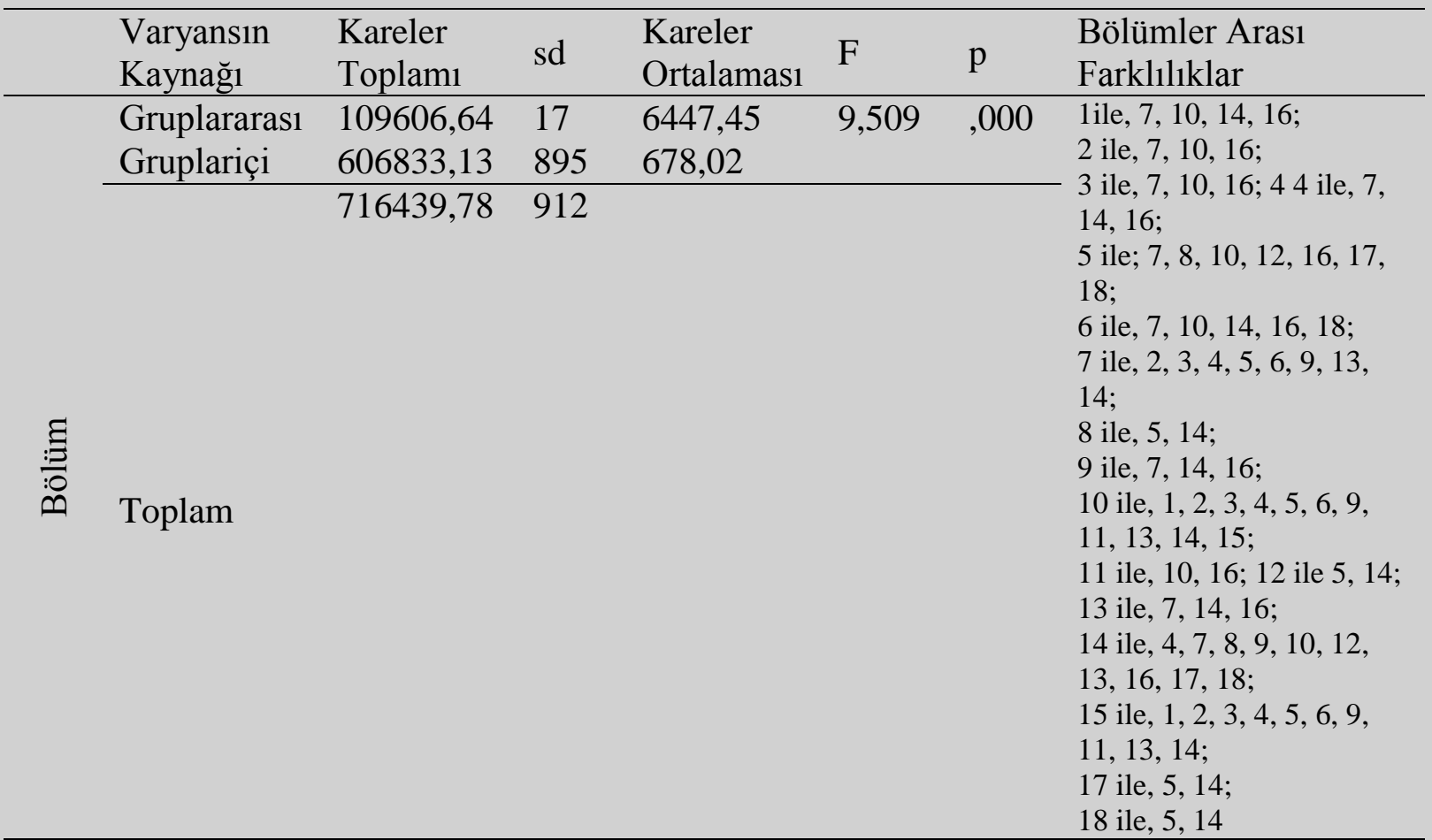


Tablo 4'de de görüldüğü gibi, ilişkisiz örneklemler için tek faktörlü varyans analizi (ANOVA) kullanılarak elde edilen bulgulara göre, katılımcıların Akademik Öz-Yeterlik Ölçeğinden aldıkları puanlar arasında, öğrenim gördükleri bölümlere göre anlamlı bir farklılık vardır $[\mathrm{F}(17-895)=9,509, \mathrm{p}<.05]$. Diğer bir ifadeyle, katılımcıların Akademik ÖzYeterlik durumları öğrenim gördükleri bölümlere göre değişmektedir. Bu farklılığın hangi gruplardan kaynaklandığını, bir başka değişle farklılığı hangi grupların yaptığını belirlemek amacıyla yapılan LSD testi sonucunda, farklılığın; Tablo 4'de de gösterildiği gibi, Sosyal bilgiler öğretmenliğinin; Din kültürü ve ahlak bilgisi, ilk öğretim matematik, Böte, biyoloji öğretmenlikleri ile, Coğrafya öğretmenliğinin; Din kültürü ve ahlak bilgisi, ilk öğretim matematik, biyoloji öğretmenlikleri ile, İngilizce öğretmenliğinin; Din kültürü ve ahlak bilgisi, ilk öğretim matematik, biyoloji öğretmenlikleri ile, Okul öncesi öğretmenliğinin; Din kültürü ve ahlak bilgisi, Böte, biyoloji öğretmenlikleri ile, Özel Eğitim öğretmenliğinin; Din kültürü ve ahlak bilgisi, fen bilgisi, resim, ilk öğretim matematik, orta öğretim matematik, biyoloji ve tarih öğretmenlikleri ile, Türkçe öğretmenliğinin; Din kültürü ve ahlak bilgisi, ilk öğretim matematik, Böte, biyoloji ve tarih öğretmenlikleri ile, Din kültürü ve ahlak bilgisi öğretmenliğinin; coğrafya, İngilizce, okul öncesi, özel eğitim, Türkçe, sınıf, pdr, Böte öğretmenlikleri ile, fen bilgisi öğretmenliğinin; Özel eğitim ve Böte öğretmenliği ile, Sınıf öğretmenliğinin; Din kültürü ve ahlak bilgisi, Böte, biyoloji öğretmenlikleri ile, ilk öğretim 
matematik öğretmenliğinin; sosyal bilgiler, coğrafya, İngilizce, okul öncesi, özel eğitim, Türkçe, sınıf, fizik, pdr, Böte ve almaca öğretmenlikleri ile; fizik öğretmenliğinin; ilk öğretim matematik ve biyoloji öğretmenlikleri ile, resim öğretmenliğinin; özel eğitim ve Böte öğretmenlikleri ile, pdr öğretmenliğinin; din kültürü ve ahlak bilgisi, Böte ve biyoloji öğretmenlikleri ile, Böte öğretmenliğinin; okul öncesi, din kültürü ve ahlak bilgisi, fen bilgisi, sınıf, ilk öğretim matematik, resim, pdr, biyoloji, orta öğretim matematik ve tarih öğretmenlikleri ile, almaca öğretmenliğinin; sosyal bilgiler, coğrafya, İngilizce, okul öncesi, özel eğitim, Türkçe, sınıf, fizik, pdr ve Böte öğretmenlikleri ile; orta öğretim matematik öğretmenliğinin; özel eğitim ve Böte öğretmenlikleri ile; tarih öğretmenliğinin; özel eğitim ve Böte öğretmenlikleri ile arasında anlamlı farklılıklar vardır.

Ayrıca, katılımcıların öğrenim gördükleri bölümler ile ölçeğin alt boyutları olan sosyal statü boyutunda $[\mathrm{F}(17-895)=9,945, \mathrm{p}(.000)<.05]$; bilişsel uygulamalar boyutunda $[\mathrm{F}(17-$ $895)=9,065, \mathrm{p}(.000)<.05]$ ve teknik beceriler alt boyutunda $[\mathrm{F}(17-895)=6,968, \mathrm{p}(.000)$ <.05] öğretmen adaylarının öğrenim gördükleri bölümlere göre farklılıklar bulunmuştur ve sonuç anlamlı çıkmıştır.

Katılımcıların Akademik Öz-Yeterlik Ölçeğinden aldıkları puanların öğrenim gördükleri sınıflara göre sonuçlar Tablo 5'de, değişkenlik gösterip göstermediğine dair bulgular Tablo 6'da verilmiştir.

Tablo 5. Akademik Öz-Yeterlik Ölçeğinden Aldıkları Puanların Öğrenim Gördükleri Sınıflara Göre Sonuçları 


\begin{tabular}{|c|c|c|c|}
\hline Siniflar & $\mathrm{N}$ & $\bar{X}$ & $\mathrm{~S}$ \\
\hline 1. sinif & 142 & 118,95 & 28,62 \\
\hline 2. sinif & 194 & 128,13 & 26,70 \\
\hline 3. sinif & 225 & 128,10 & 27,69 \\
\hline 4. sinif & 298 & 125,39 & 27,99 \\
\hline 5. sinif & 54 & 114,24 & 28,49 \\
\hline Toplam & 913 & 124,98 & 28,02 \\
\hline
\end{tabular}

Tablo 6. Katılımcıların Akademik Öz-Yeterlik Ölçeği Toplam Puanlarının Öğrenim Görülen Sınıf Değişkenine Göre Farklılığı İçin Tek Yönlü Varyans Analizi (ANOVA) Sonuçları

\begin{tabular}{|c|c|c|c|c|c|c|c|}
\hline & $\begin{array}{l}\text { Varyansın } \\
\text { Kaynağ1 }\end{array}$ & $\begin{array}{l}\text { Kareler } \\
\text { Toplamı }\end{array}$ & sd & $\begin{array}{c}\text { Kareler } \\
\text { Ortalamas1 }\end{array}$ & $\mathrm{F}$ & $\mathrm{p}$ & $\begin{array}{c}\text { Sinıflar arası } \\
\text { farklılıklar }\end{array}$ \\
\hline \multirow[b]{3}{*}{ 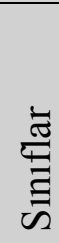 } & Gruplararası & 15571,88 & 4 & 3892,97 & 5,043 & ,001 & \multirow{3}{*}{$\begin{array}{l}1 \text { ile, } 2 \text { ve } 3 ; \\
2 \text { ile, } 1 \text { ve } 5 ; \\
3 \text { ile, } 1 \text { ve } 5 ; \\
4 \text { ile, } 1 \text { ve } 5 ; \\
5 \text { ile, } 2,3 \text { ve } 4\end{array}$} \\
\hline & Gruplariçi & 700867,89 & 908 & 771,88 & & & \\
\hline & Toplam & 716439,78 & 912 & & & & \\
\hline
\end{tabular}

Tablo 6’da da görüldüğü gibi, ilişkisiz örneklemler için tek faktörlü varyans analizi (ANOVA) kullanılarak elde edilen bulgulara göre, katılımcıların Akademik Öz-Yeterlik Ölçeğinden aldıkları puanlar arasında, öğrenim gördükleri sınıflara göre anlamlı bir farklılık vardır $[\mathrm{F}(4-908)=9,509, \mathrm{p}<.05]$. Diğer bir ifadeyle, katılımcıların Akademik Öz-Yeterlik durumları öğrenim gördükleri sınıflara göre değişmektedir. Bu farklılığın hangi gruplardan kaynaklandığını, bir başka değişle farklılığı hangi grupların yaptığını belirlemek amacıyla yapılan Lsd testi sonucunda, farklılığın; Tablo 6'da da gösterildiği gibi; 1 . Sınıfların; 2 ve 3 ile; 2. Sinıfların; 1 ve 5 ile; 3 . Sinıfların; 1 ve 5 ile; 4 . Sinıfların; 1 ve 5 ile; 5 . Sinıfların; 2 , 3 ve 4 sınıflar ile aralarında anlamlı farklılıklar vardır.

Katılımcıların Akademik Öz-Yeterlik Ölçeğinden aldıkları puanların mezun oldukları 
lise türlerine göre sonuçları Tablo 7'de, değişkenlik gösterip göstermediğine dair bulgular

Tablo 8'de verilmiştir.

Tablo 7. Akademik Öz-Yeterlik Ölçeğinden Aldıkları Puanların Mezun Oldukları Lise Türlerine Göre Sonuçları

\begin{tabular}{llll}
\hline $\begin{array}{l}\text { Mezun oldukları lise } \\
\text { türü }\end{array}$ & $\mathrm{N}$ & $\bar{X}$ & $\mathrm{~S}$ \\
\hline 1 Normal & 313 & 122,22 & 28,23 \\
2 Anadolu & 335 & 124,65 & 26,59 \\
3 Süper & 13 & 124,30 & 24,94 \\
4 Ticaret & 17 & 125,82 & 30,96 \\
5 Meslek & 136 & 130,93 & 28,03 \\
6Teknik & 36 & 135,55 & 31,54 \\
7 Diğer & 63 & 121,46 & 29,99 \\
\hline Toplam & 913 & 124,98 & 28,02 \\
\hline
\end{tabular}

Tablo 8. Katılımcıların Akademik Öz-Yeterlik Ölçeği Toplam Puanlarının Mezun Oldukları Lise Türü Değişkenine Göre Farklılığı İçin Tek Yönlü Varyans Analizi (ANOVA) Sonuçları Sonuçları

\begin{tabular}{|c|c|c|c|c|c|c|c|}
\hline & $\begin{array}{l}\text { Varyansın } \\
\text { Kaynağı }\end{array}$ & $\begin{array}{l}\text { Kareler } \\
\text { Toplamı }\end{array}$ & $\mathrm{sd}$ & $\begin{array}{l}\text { Kareler } \\
\text { Ortalamas1 }\end{array}$ & $\mathrm{F}$ & $\mathrm{p}$ & $\begin{array}{l}\text { Lise türü aras1 } \\
\text { farklılıklar }\end{array}$ \\
\hline \multirow{3}{*}{ 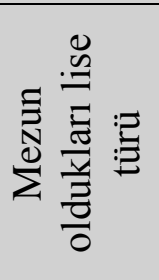 } & Gruplarar & 12053,18 & 6 & 2008,86 & 2,584 & ,01 & \multirow{3}{*}{$\begin{array}{l}1 \text { ile, } 5 \text { ve } 6 ; \\
2 \text { ile, } 5 \text { ve } 6 ; \\
5 \text { ile, } 1,2 \text { ve } 7 ; \\
6 \text { ile, } 1,2 \text { ve } 7 ; \\
7 \text { ile, } 5 \text { ve } 6\end{array}$} \\
\hline & & 704386,60 & 906 & 777,46 & & & \\
\hline & Toplam & 716439,78 & 912 & & & & \\
\hline
\end{tabular}

Tablo 5'de de görüldüğü gibi, ilişkisiz örneklemler için tek faktörlü varyans analizi

(ANOVA) kullanılarak elde edilen bulgulara göre, katılımcıların Akademik Öz-Yeterlik Ölçeğinden aldıkları puanlar arasında, mezun oldukları lise türlerine göre anlamlı bir farklılık vardır $[\mathrm{F}(6-906)=2,584, \mathrm{p}<.05]$. Diğer bir ifadeyle, katılımcıların Akademik Öz-Yeterlik durumları mezun oldukları lise türlerine göre değişmektedir. Bu farklılığın hangi gruplardan kaynaklandığını, bir başka değişle farklılığı hangi grupların yaptığını belirlemek amacıyla 
yapılan LSD testi sonucunda, farklılığın; Tablo 8'den de gösterildiği gibi; normal liseden mezun olanlarla; meslek lisesi ve teknik liseden mezun olanlar ile; Anadolu lisesinden mezun olanlar ile; meslek lisesi ve teknik liseden mezun olanlar ile; meslek lisesinden mezun olanlar ile; normal lise, Anadolu lisesi ve diğer liselerden mezun olanlar ile; teknik liseden mezun olanlar; normal lise, Anadolu lisesi ve diğer liselerden mezun olanlar ile; diğer liselerden mezun olanlar ile; meslek lisesinden mezun olanlar ile teknik liseden mezun olanlar arasında anlamlı farklılıklar bulunmaktadır.

Katılımcıların Akademik Öz-Yeterlik Ölçeğinden aldıkları puanların internete sahip olma durumlarına göre değişkenlik gösterip göstermediğine dair bulgular Tablo 9'da verilmiştir.

Tablo 9.Katılımcıların Akademik Öz-Yeterlik Ölçeği Toplam Puanlarının İnternete Erişim Durumlarına Göre t-Testi Sonuçları

\begin{tabular}{lllllll}
\hline Gruplar & $\mathrm{N}$ & $\bar{X}$ & $\mathrm{~S}$ & $\mathrm{Sd}$ & $\mathrm{t}$ & $\mathrm{p}$ \\
\hline Evet & 804 & 125,9478 & 27,87992 & 911 & 2,831 &, 005 \\
Hayır & 109 & 117,8807 & 28,22355 & & & \\
\hline$* \mathrm{p}<0.05$ & & & & &
\end{tabular}

Tablo 9’ da görüldüğ̈ gibi *p<.05 anlamlılık düzeyi için $.005<.05$ olduğu için sonuç anlamlıdır. Katılımcıların Akademik Öz-Yeterlik Ölçeğinden aldıkları puanların ortalaması (evet ortalaması $\bar{X}=125,94$; hayır ortalaması $\bar{X}=117,88$ ) birbirinden farklı çıkmıştır, dolayısıyla Tablo 6'dan da görüldügü gibi ${ }^{*} p<.05$ anlamlılık düzeyi için $.005<.05$ 'dir ve sonuç anlamlıdır. Bir başka değişle katılımcıların Akademik Öz-Yeterlik Ölçeğinden aldıkları puanların internete erişim durumlarına göre anlamlı bir farklılık göstermektedir. 
Katılımcıların Akademik Öz-Yeterlik Ölçeğinden aldıkları puanların mezun oldukları haftalık internet kullanım süresine göre sonuçlar Tablo 10'da, değişkenlik gösterip göstermediğine dair bulgular Tablo 11 'de verilmiştir.

Tablo 10. Akademik Öz-Yeterlik Ölçeğinden Aldıkları Puanların Haftalık İnternet Kullanım Sürelerine Göre Sonuçları

\begin{tabular}{llll}
\hline $\begin{array}{l}\text { Haftalik internet } \\
\text { kullanım süresine }\end{array}$ & $\mathrm{N}$ & $\bar{X}$ & $\mathrm{~S}$ \\
\hline 1. 0-3 saat & 172 & 119,35 & 27,46 \\
2. 3-6 saat & 235 & 122,99 & 27,08 \\
3. 6-9 sat & 175 & 120,05 & 27,75 \\
4. 9 saat ve üzeri & 331 & 131,93 & 27,80 \\
\hline Toplam & 913 & 124,98 & 28,02 \\
\hline
\end{tabular}

Tablo 11. Katılımcıların Akademik Öz-Yeterlik Ölçeği Toplam Puanlarının Haftalık İnternet Kullanım Süresi Değişkenine Göre Farklılığı İçin Tek Yönlü Varyans Analizi (ANOVA) Sonuçları

\begin{tabular}{llllllll}
\hline & $\begin{array}{l}\text { Varyansın } \\
\text { Kaynağı }\end{array}$ & $\begin{array}{c}\text { Kareler } \\
\text { Toplamı }\end{array}$ & sd & $\begin{array}{c}\text { Kareler } \\
\text { Ortalaması }\end{array}$ & F & p & $\begin{array}{c}\text { Haftalık internet } \\
\text { kullanım süresi } \\
\text { arası farklılıklar }\end{array}$ \\
\hline $\begin{array}{l}\text { Haftalık } \\
\begin{array}{l}\text { internet } \\
\text { kullanım } \\
\text { süresine }\end{array}\end{array}$ & Gruplararası & 26609,48 & 3 & 8869,82 & 11,68 &, 000 & 1 ile 4 arasında; \\
& Gruplariçi & 689830,30 & 909 & 758,88 & & & \\
\hline
\end{tabular}

Tablo 11'de de görüldüğü gibi, ilişkisiz örneklemler için tek faktörlü varyans analizi

(ANOVA) kullanılarak elde edilen bulgulara göre, katılımcıların Akademik Öz-Yeterlik

Ölçeğinden aldıkları puanlar arasında, Haftalık internet kullanım süresine göre anlamlı bir farklılık vardır $[\mathrm{F}(3-909)=11,68, \mathrm{p}<.05]$. Diğer bir ifadeyle, katılımcıların Akademik ÖzYeterlik durumları Haftalık internet kullanım süresine göre değişmektedir. Bu farklılığın hangi gruplardan kaynaklandığını, bir başka değişle farklılığı hangi grupların yaptığını 
belirlemek amacıyla yapılan LSD testi sonucunda, Tablo 11'de de gösterildiği gibi farklılığın;

Haftalık internet kullanım süresi 0-3 saat olanlarla; 9 saat ve üzeri olanlar ile, Haftalık internet kullanım süresi 3-6 saat olanlarla; 9 saat ve üzeri olanlar ile, Haftalık internet kullanım süresi 6-9 saat olanlarla; 9 saat ve üzeri olanlar arasında anlamlı farklılıklar bulunmaktadır.

Katılımcıların Akademik Öz-Yeterlik Ölçeğinden aldıkları puanların mobil cihaz kullanım yeterlilik düzeylerine göre sonuçları Tablo $12^{\prime}$ de, değişkenlik gösterip göstermediğine dair bulgular Tablo 13'de verilmiştir.

Tablo 12. Akademik Öz-Yeterlik Ölçeğinden Aldıkları Puanların Mobil Cihaz Kullanım Yeterlilik Düzeylerine Göre Sonuçları

\begin{tabular}{llll}
$\begin{array}{l}\text { Mobil cihaz kullanım } \\
\text { yeterlilik düzeylerine }\end{array}$ & $\mathrm{N}$ & $\bar{X}$ & $\mathrm{~S}$ \\
\hline 1 Çok yetersiz & 19 & 115,63 & 24,54 \\
2 Yetersiz & 47 & 114,44 & 29,67 \\
3 Orta düzeyde yeterli & 276 & 120,08 & 25,49 \\
4 Yeterli & 390 & 127,53 & 27,64 \\
5 Çok yeterli & 181 & 130,67 & 30,47 \\
\hline Toplam & 913 & 124,98 & 28,02 \\
\hline
\end{tabular}

Tablo 13. Katılımcıların Akademik Öz-Yeterlik Ölçeği Toplam Puanlarının Mobil Cihaz Kullanım Yeterlilik Düzeyleri Değişkenine Göre Farklılığı İçin Tek Yönlü Varyans Analizi (ANOVA) Sonuçları

\begin{tabular}{|c|c|c|c|c|c|c|c|}
\hline \multirow{4}{*}{ 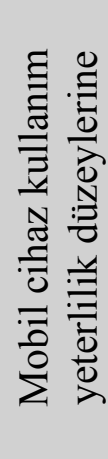 } & $\begin{array}{l}\text { Varyansın } \\
\text { Kaynağı }\end{array}$ & $\begin{array}{l}\text { Kareler } \\
\text { Toplamı }\end{array}$ & $\mathrm{sd}$ & $\begin{array}{l}\text { Kareler } \\
\text { Ortalaması }\end{array}$ & $\mathrm{F}$ & $\mathrm{p}$ & $\begin{array}{c}\text { Mobil cihaz } \\
\text { kullanım yeterlilik } \\
\text { düzeyleri arası } \\
\text { farklılıklar }\end{array}$ \\
\hline & Gruplararası & 21905,35 & 4 & 5476,33 & 7,159 & ,000 & \multirow{3}{*}{$\begin{array}{l}1 \text { ile } 5 ; \\
2 \text { ile } 4 \text { ve } 5 ; \\
3 \text { ile } 4 \text { ve } 5 ; \\
4 \text { ile } 2 \text { ve } 3 ; \\
5 \text { ile } 2 \text { ve } 3 ;\end{array}$} \\
\hline & Gruplariçi & 694534,43 & 908 & 764,90 & & & \\
\hline & Toplam & 716439,78 & 912 & & & & \\
\hline
\end{tabular}


Tablo 13'de de görüldüğü gibi, ilişkisiz örneklemler için tek faktörlü varyans analizi (ANOVA) kullanılarak elde edilen bulgulara göre, katılımcıların Akademik Öz-Yeterlik Ölçeğinden aldıkları puanlar arasında, mobil cihaz kullanım yeterlilik düzeylerine göre anlamlı bir farklılık vardır $[\mathrm{F}(4-908)=7,159 \mathrm{p}<.05]$. Diğer bir ifadeyle, katılımcıların Akademik Öz-Yeterlik durumları mobil cihaz kullanım yeterlilik düzeylerine göre değişmektedir. Bu farklılığın hangi gruplardan kaynaklandığını, bir başka değişle farklılığı hangi grupların yaptığını belirlemek amacıyla yapılan LSD testi sonucunda, Tablo 13'de de gösterildiği gibi farklılığın; Mobil cihaz kullanım yeterlilik düzeyi çok yetersiz olanlar ile çok yeterli olanlar arasında; mobil cihaz kullanım yeterlilik düzeyi yetersiz olanlar ile yeterli ve çok yeterli olanlar arasında; mobil cihaz kullanım yeterlilik düzeyi orta düzeyde yeterli olanlar ile yeterli ve çok yeterli olanlar arasında; Mobil cihaz kullanım yeterlilik düzeyi yeterli olanlar ile yetersiz ve orta düzeyde yeterli olanlar arasında; Mobil cihaz kullanım yeterlilik düzeyi çok yeterli olanlar ile yetersiz ve orta düzeyde yeterli olanlar arasında anlamlı farklılıklar bulunmaktadır.

Katılımcıların Akademik Öz-Yeterlik Ölçeğinden aldıkları puanların Mobil cihaz sahiplik sürelerine göre sonuçları Tablo $14^{\prime}$ de, değişkenlik gösterip göstermediğine dair bulgular Tablo 15'de verilmiştir.

Tablo 14. Akademik Öz-Yeterlik Ölçeğinden Aldıkları Puanların Mobil Cihaz Sahiplik Sürelerine Göre Sonuçları

\begin{tabular}{llll}
\hline Mobil cihaz sahiplik & $\mathrm{N}$ & $\mathrm{X}$ & $\mathrm{S}$
\end{tabular}


sürelerine

1. 0-2 yildir

77

116,2078

25,35658

2. 2-4 yildir

163

121,0000

25,99121

3. 4 yıldan fazla

673

126,9539

28,53067

Toplam

913

124,9847

28,02802

Tablo 15. Katılımcıların Akademik Öz-Yeterlik Ölçeği Toplam Puanlarının Mobil Cihaz Sahiplik Süreleri Değişkenine Göre Farklılığı İçin Tek Yönlü Varyans Analizi (ANOVA) Sonuçlarına Göre Sonuçları

\begin{tabular}{|c|c|c|c|c|c|c|c|}
\hline \multirow{4}{*}{ 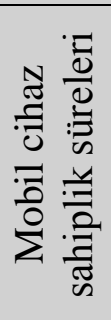 } & $\begin{array}{l}\text { Varyansın } \\
\text { Kaynağ1 }\end{array}$ & $\begin{array}{l}\text { Kareler } \\
\text { Toplamı }\end{array}$ & sd & $\begin{array}{l}\text { Kareler } \\
\text { Ortalamas1 }\end{array}$ & $\mathrm{F}$ & $\mathrm{p}$ & $\begin{array}{c}\text { Mobil cihaz } \\
\text { sahiplik süreleri } \\
\text { arası farklılıklar }\end{array}$ \\
\hline & Gruplararası & 11129,538 & 2 & 5564,769 & 7,180 &, 001 & \multirow{3}{*}{$\begin{array}{l}1 \text { ile } 4 ; \\
2 \text { ile } 4 ; \\
3 \text { ile } 1 \text { ve } 2 ;\end{array}$} \\
\hline & Gruplariçi & 705310,247 & 910 & 775,066 & & & \\
\hline & Toplam & 716439,785 & 912 & & & & \\
\hline
\end{tabular}

Tablo $15^{\prime}$ de de görüldüğü gibi, ilişkisiz örneklemler için tek faktörlü varyans analizi

(ANOVA) kullanılarak elde edilen bulgulara göre, katılımcıların Akademik Öz-Yeterlik

Ölçeğinden aldıkları puanlar arasında, Mobil cihaz sahiplik sürelerine göre anlamlı bir farklılık vardır $[\mathrm{F}(2-910)=7,180 \mathrm{p}<.05]$. Diğer bir ifadeyle, katılımcıların Akademik ÖzYeterlik durumları Mobil cihaz sahiplik sürelerine göre değişmektedir. Bu farklılığın hangi gruplardan kaynaklandığını, bir başka değişle farklılığı hangi grupların yaptığını belirlemek

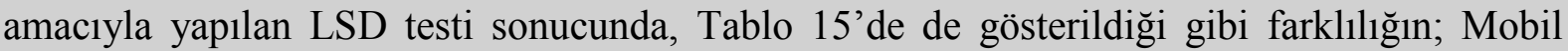
cihaz sahiplik süresi 0-2 yıl olanlar ile 4 yıldan fazla olanların, Mobil cihaz sahiplik süresi 24 yıl olanlar ile 4 yıldan fazla olanların ve Mobil cihaz sahiplik süresi 4 yıldan fazla olanlar ile 0-2 yıl olanlar ve 2-4 yıl olanlar arasında farklılık bulunmuştur.

Katılımcıların Akademik Öz-Yeterlik Ölçeğinden aldıkları puanları ile yaşları 
arasındaki ilişkiye dair bulgular Tablo 16'da verilmiştir. Akademik Öz-Yeterlik Ölçeğinden aldıkları puanları ile yaşları arasındaki ilişkinin belirlenmesinde basit korelasyon tekniğinden yararlanılmıştır.

Tablo 16. Katılımcıların Akademik Öz-Yeterlik Ölçeğinden Aldıkları Toplam Puanları İle Yaşları Arasındaki İlişkinin Sonuçları

\begin{tabular}{ll}
\hline & Yaş \\
\hline Akademik Öz-Yeterlik Durumları & $.122 *(\mathrm{p}=.000)$ \\
\hline
\end{tabular}

*Korelasyon 0.01 düzeyinde anlamlıdır.

Tablo 10’da da görüldüğü gibi, Akademik Öz-Yeterlik Ölçeğinden aldıkları puanları ile yaşları arasında; düşük düzeyde, pozitif yönlü ve anlamlı bir ilişki bulunmaktadır, r=.014, $\mathrm{p}<.01$. $\mathrm{Bu}$ sonuca göre Akademik Öz-Yeterlik durumlarının, yaşları arttıkça arttığ söylenebilir. Determinasyon katsayısı $\left(r^{2}=.014\right)$ dikkate alındığında, Akademik Öz-Yeterlik durumlarına yönelik puanlarının artışındaki toplam varyansın (değişkenliğin) \% 1,4’ü yaşlarından kaynaklandığı söylenebilir.

\section{Sonuç Ve Tartışma}

Eğitim fakültesinde farklı branşlarda ve farklı sınıflarda öğrenim gören öğretmen adaylarından oluşan çalışma grubunun, akademik öz-yeterlik durumlarının farklı değişkenler açısından belirlenmesini amaçlayan bu çalışmada ortaya çıkan sonuca göre; öğretmen adaylarının akademik öz-yeterliklerinin öğrenim gördükleri bölümlere göre değişmektedir. $\mathrm{Bu}$ sonuca benzer sonuçlar, Çapri ve Çelikkaleli (2008), Erişen ve Çeliköz (2003) ile 
benzerlik göstermektedir. Bulgularda da belirtilen öğrenim görülen bölümler arasında ki farklılıkların, ortaöğretim matematik bölümü öğretmen adaylarınki, fen eğitimi alanlarındaki fizik, kimya ve biyoloji bölümleri öğretmen adaylarına göre yüksek olduğu sonucuna ulaşılmıştır. Ayrıca, öğretmen adaylarının öz yeterlik inançlarının branşa göre değiştiğine ilişskin bu bulgular; Azar ve Akıncı (2009) tarafından yapılan araştırmanın sonucu ile de benzerlik göstermektedir. Bölümleri değiştikçe akademik öz-yeterlik düzeylerinin de farklılaşmasının sebepleri olarak; Öğrenci Seçme Sınavı'ndaki bölümlere yerleştikleri giriş puanları ve öğretmen adaylarının öğrenim gördükleri bölümlerdeki dersler gösterilebilir. Çünkü yapılan araştırmalar, özyeterlik algısının, başarıyı etkilediğini göstermektedir; özyeterlik algısı yüksek olan öğrenciler, matematiksel çalışmaları seçmekte, gayret göstermekte ve engelleri aşarak, özyeterlik algısı düşük olanlara göre daha başarılı olmaktadır (Schunk ve Zimmerman, 1998). Ayrıca Demirok (1990) çalışmasında, üniversite öğrencilerinin ÖYS: TM, TS ve S puanları ile üniversite başarıları puanları arasında anlamlı bir ilişki bulmuştur.

Öğretmen adaylarının öğrenim gördükleri sınıflara göre akademik öz-yeterlik ölçeğinden aldıkları puanlar değişmektedir. Benzer sonuçlara Durdukoca'nın (2010) yaptığı araştırmanın sonucunda rastlanmaktadır. Bu bulgular doğrultusunda, öğretmen adaylarının geçirdikleri öğrenim yaşantılarının akademik öz-yeterlik inançlarını daha güçlü hale getirdiği söylenebilir. Sınıf değişkenine göre elde edilen bu bulgular, yaş değişkenine göre elde edilen 
bulgularla da desteklenmektedir.

Öğretmen adaylarının akademik öz-yeterlik durumları mezun oldukları lise türlerine göre değişmektedir. Gerçek, Yılmaz, Köseoğlu ve Soran (2006)'ın yaptıkları çalışmanın bulgusu ile farklılaşmaktadır. Akademik Öz-Yeterlik Ölçeğinden aldıkları puanların internete sahip olma durumlarına göre ve haftalık internet kullanım süresine göre değişmektedir. Tsai, Lin ve Tsai (2001) ve Kyounghee-Lim (2009) yaptıkları çalışmalarda benzer sonuçlar bulmuşlardır. Öğretmen adaylarının, internetle etkileşim durumları arttıkça bilgi ve iletişim teknolojilerine yönelik tutumları da artmaktadır. Bilgi ve iletişim teknolojilerine yönelik tutumlarındaki olumlu gelişme; akademik öz-yeterlik durumlarını da olumlu olarak etkilemektedir. Bir başka çalışmada Orhan (2005), üniversite son sınıf öğrenciler ile yaptığı çalışmada, öğretmen adaylarının öğretmenlik öz-yeterlik inançları ile bilgisayar öz-yeterlik inançları arasında pozitif ve oldukça yüksek bir ilişki olduğunu ortaya koymuştur. Yapılan bu çalışma ile elde edilen bulgular bahsedilen araştırmaların sonuçlarını desteklemektedir.

Akademik öz-yeterlik durumları mobil cihaz sahiplik sürelerine ve mobil cihaz kullanım yeterlilik düzeylerine göre değişmektedir. Sorgo, Verckovnik ve Kocijancic (2010) yapmış oldukları çalışmada, öğretmenlerin teknolojiye yönelik algıları, yeterlilikleri ve kullanım sıklığı arasında yüksek bir ilişki olduğu sonucunu ortaya koymuşlardır. Benzer bir sonuç; Gibbone, Rukavina ve Silverman (2010) yapmış oldukları çalışmada öğretmenlerin, teknolojileri öğretim süreçlerine entegrasyonunda gösterdikleri tutumları ve teknoloji 
kullanım yeterlilikleri arasındaki ilişkiyi inceledikleri çalışmanın sonucunda vardır. Yapılan bu çalışma ile elde edilen bulgular bahsedilen araştırmaların sonuçlarını desteklemektedir.

Akademik Öz-Yeterlik Ölçeğinden aldıkları puanları ile yaşları arasında; düşük düzeyde, pozitif yönlü ve anlamlı bir ilişki bulunmaktadır, $r=.014, p<.01$. Bu sonuca göre Akademik Öz-Yeterlik durumlarının, yaşları arttıkça arttı̆̆ı söylenebilir. Determinasyon katsayısı ( $\left.\mathrm{r}^{2}=.014\right)$ dikkate alındığında, Akademik Öz-Yeterlik durumlarına yönelik puanlarının artışındaki toplam varyansın (değişkenliğin) \% 1,4’ü yaşlarından kaynaklandığı söylenebilir. Benzer sonuç Kyounghee-Lim (2009) yaptı̆̆ı çalışmanın bulgularında rastlanmıştır. Kyounghee-Lim öz-yeterlikle yaş ilişkisine ait korelasyonu r=.187 olarak bulmuştur.

\section{Öneriler}

$\mathrm{Bu}$ araştırmanın sonuçlarına göre; öğretmen adaylarının akademik öz-yeterlik durumları mezun oldukları lise türlerine göre değişmektedir. Bu bulgudan hareketle, öğrencilerin üniversiteye geçmeden önce bireysel öz-yeterliklerinin artırılması için; eğitim ve öğretim hayatına yönelik motivasyonlarının, olumlu tutumlarının artırılmasını sağlayan öğrenim yaşantıları sunulmalıdır. Öğretmen adaylarının teknolojik yeterliliklerinin artmasının (haftalık internet kullanım süresi, mobil cihaz kullanım sahipliği, yeterliliği ve süresi) akademik öz-yeterliklerine olumlu etkileri olduğu bulgusuna ulaşılmıştır. Bu bulguya göre, bireylerin teknolojik yetkinliklerinin ve etkileşimlerinin artırılması, ders içi ve ders dış1 
faaliyetlerde teknolojinin yaşamlarına entegrasyonun desteklenmesi önerilmektedir. $\mathrm{Bu}$ araştırmanın çalışma grubunu bir devlet üniversitesinde bulunan eğitim fakültesindeki farklı branşlardan oluşan öğretmen adayları oluşturmuştur. Farklı üniversitelerde bulunan eğitim fakültelerinde öğrenim gören öğretmen adaylarının da katıldığı daha geniş çalışma grupları ile çalışma yapılabilir. Ayrıca, akademik öz-yeterliğe etki eden farklı değişkenler ele alınarak çalışmalar yapılabilir. Akademik öz-yeterlik inançları üzerinde farklı ölçekleri de işe koşmak, gelecekte yapılacak olan çalışmalar için önerilmektedir.

\section{Makalenin Bilimdeki Konumu}

Eğitim Bilimleri ve Öğretmen Yetiştirme Temel Alanı / Bilgisayar ve Öğretim Teknolojileri Anabilim Dalı.

\section{Makalenin Bilimdeki Özgünlüğü}

Öz-yeterlik inancı, birey davranışlarının en önemli yordayıcılarından birisidir. Ayrıca, akademik öz-yeterlik kavramı, bireylerin belirlenen bir akademik görevi istenilen başarı düzeyine göre yapabileceği konusundaki isteklilik durumlarını etkilemektedir. Dolayısıyla, eğitim öğretim faaliyetlerinin amacına ulaşmasında, öğretmen adaylarının öğrenim hayatlarında akademik öz-yeterliklerinin algılarının farklı değişkenlere göre belirlenmesi ve akademik öz-yeterlik algı düzeylerinin geliştirilmesi önemlidir. Amacı, eğitim fakültelerinde lisans öğrenimi gören öğrencilerin akademik öz-yeterlik algılarını belirlemek olan bu çalışma, 
farklı özellikler taşıyan öğretmen adaylarının akademik öz-yeterlik durumlarını belirlemeye çalışmış ve bulgular ışığından öneriler getirerek, alana katkı sağlamaya çalışmıştır.

\section{Kaynaklar}

Aşkar, P. ve Umay, A. (2001). İlköğretim matematik öğretmenliği öğrencilerinin bilgisayarla ilgili öz-yeterlik algısı. Hacettepe Üniversitesi Eğitim Fakültesi Dergisi, 21, 1-8.

Azar, A., ve Akıncı, M. (2009). Öğretmen adaylarının öğretmen öz-yeterlik inancı, akademik başarı ve kpss başarıları arasındaki ilişkinin çeşitli değişkenler açısından yordanması. 7. Ulusal Fen ve Matematik Eğitimi Kongresi.

Bandura, A. (1977). Social learning theory. Engle wood Cliffs, NJ: Prentice Hall.

Bandura, A. (1994). Self-efficacy in V. S. Ramachaudran (Ed.) Encyclopedia of Human Behavior, 4, 71-81. New York: Academic Press.

Bandura, A. (1995). Exercise of personal and collective efficacy in changing societies. Selfefficacy in changing societies. Cambridge University Press.

Bandura, A. (1997). Self-efficacy: the exercise of control. New York: W. H. Freeman and Company.

Bandura, A. (1997a). Self-efficacy in changing societies. In Bandura, A. (Ed.) Exercise of personal and collective efficacy in changing societies (1-45). New York: Cambridge University Press.

Bedel, E. F. (2016). Exploring academic motivation, academic self-efficacy and attitude 
stoward teaching in pre-service early childhood education teachers. Journal of Educationand Training Studies, 4(1), 142-149.

Çapri, B., ve Çelikkaleli, Ö. (2008). Öğretmen adaylarının öğretmenliğe ilişkin tutum ve mesleki yeterlik inançlarının cinsiyet, program ve fakültelerine göre incelenmesi. İnönü Üniversitesi Ĕ̆itim Fakültesi Dergisi, 9(15), 33-53.

Demirok, S.(1990). ÖSS ve ÖYS puanları ile lise ve dengi okullardaki başarının yükseköğretimdeki başarıyla ilişkisi. Yayımlanmamış Yüksek Lisans Tezi: Hacettepe Üniversitesi: Ankara

Durdukoca, Ş. F. (2010). Sınıf öğretmeni adaylarının akademik öz-yeterlik algılarının çeşitli değişkenler açısından incelenmesi. Abant İzzet Baysal Üniversitesi Dergisi, 10(1).

Ekici, G. (2012). Akademik öz-yeterlik ölçeği: Türkçe’ye uyarlama, geçerlik ve güvenirlik çalışması. Hacettepe Üniversitesi Ĕ̈itim Fakültesi Dergisi, 43(43).

Erisen, Y., ve Çeliköz, N. (2003). Öğretmen adaylarının genel öğretmenlik davranışları açısından kendilerine yönelik yeterlilik algıları. Türk Eğitim Bilimleri Dergisi, 1(4), 427-439.

Gerçek, C., Yılmaz, M., Köseoğlu, P., ve Soran, H. (2006). Biyoloji eğitimi öğretmen adaylarının öğretiminde öz-yeterlik inançları. Ankara Üniversitesi Eğitim Bilimleri Fakültesi Dergisi, 39(1), 57-73.

Gibbone, A., Rukavina, P. and Silverman, S. (2010). Technology integration in secondary 
physical education: teachers' attitudes and practice. Journal of Educational Technology Development and Exchange, 3(1), 27-42.

Jerusalem, M. (2002). Theroretischer Teil. Einleitung I, Zeitschrift für Pädagogik, 44, 8-12.

Kyounghee-Lim, C. (2009). Computer self-efficacy, academic self-concept, and other predictors of satisfaction and future participation of adult distance learners. American Journal of Distance Education, 15(2), 41-51.

Lent, R. W., Brown, S. D., and Larkin, K.C. (1986). Self-efficacy in the prediction of academic performance and perceived career options. Journal of Counseling Psychology, 33, 265-269.

Matoti, S. N. (2011) Measuring the academic self-efficacy of students at a south african higher education institution, Journal of Psychology in Africa, 21(1), 151-154.

Orhan, F. (2005). Bilgisayar öğretmen adaylarının, bilgisayar kullanma özyeterlik inancı ile bilgisayar öğretmenliği öz-yeterlik inancı üzerine bir çalışma. Eğitim Araştırmaları, $21,173-186$

Owen, S. V., and Froman, R. D. (1988). Development of a College Academic Self-Efficacy Scale. Paper presented at the Annual Meeting of the National Council on Measurement in Education.

Schunk, D.H. (1991). Self-efficacy and academic motivation. Educational Psychologist, 26, 207-231. 
Schunk, D.H. ve Zimmerman, Barry J.,(1998). Self- Regulated Learning From Teaching to Self Reflective Practice. New York: Guilford Press.

Shell, D. F., Murphy, C. C., and Bruning, R. H. (1989). Self-efficacy and outcome expectancy mechanisms in reading and writing achievement. Journal of Educational Psychology, 81, 91-100.

Sorgo, A., Verckovnik, T. and Kocijancic, S. (2010). Information and communication technologies (ict) in biology teaching in slovenian secondary schools. Eurasia Journal of Mathematics, Science and Technology Education, 6(1), 37-46.

Tsai, C.-C., Lin, S. S. J. and Tsai, M.-J. (2001). Developing an internet attitude scalefor high school students. Computers and Education, 37(1), 41-51.

Turgut, M. (2013). Academic self- efficacy beliefs of undergraduate mathematics education students. Acta Didactica Napocensia, 6(1),33-39.

Yılmaz, M., Gürçay, D. ve Ekici, G. (2007). Akademik öz-yeterlik ölçeğinin Türkçeye uyarlanması. Hacettepe Üniversitesi Ĕ̌itim Fakültesi Dergisi, 33, 253-259.

Zimmerman, B. J. (2000). Self-efficacy: An essential motive to learn. Contemporary Educational Psychology,25, 82-91. 